\title{
INTERNALISASI REVOLUSI MENTAL DALAM PENDIDIKAN ISLAM
}

\author{
Rubini \\ Dosen Program Studi Pendidikan Agama Islam \\ Sekolah Tinggi Agama Islam Masjid Syuhada Yogyakarta \\ rubinihr80@gmail.com
}

\begin{abstract}
Abstrak
Pendidikan memiliki kekuatan yang sangat besar dalam mempertahankan suatu bangsa dari yang disebut penjajah. Dengan pendidikan pulan suatu bangsa dapat mencapai kemajuan-kemajuan dan perkembangan-perkembangan yang dapat membawa mewujudkan cita-cita bangsa. Menurut Kamus Besar Bahasa Indonesia, revolusi adalah perubahan yang cukup mendasar dalam suatu bidang, sedangkan mental adalah bersangkutan dengan batin dan watak manusia, yang bukan bersifat badan dan tenaga. Revolusi mental menyangkut keadaan kejiwaan, roh, spiritual, dan nilai-nilai yang diyakini oleh seseorang atau sekelompok orang dalam sebuah ruang lingkup kecil atau bahkan sebuah negara. Internalisasi Revolusi Mental dalam Pendidikan Islam adalah pendalaman perubahan yang mendasar dalam mentalitas, cara berfikir, cara merasa, dan cara mempercayai, yang semuanya menjelma dalam perilaku dan tindakan sehari-hari dalam pendidikan Islam. Hal ini dapat dilakukan melalui: Strategi Keteladanan (modelling), Latihan dan Pembiasaan, Metode Mengambil Pelajaran, Strategi Pemberian Nasehat, Metode Kedisiplinan.
\end{abstract}

Kata Kunci: Revolusi, Mental, Internalisasi, Pendidikan, Islam

\section{Abstract}

Education has enormous power in defending a nation from the socalled invaders. With the education of a nation, people can achieve advancements and developments that can bring national ideals to life. According to the Big Indonesian Dictionary, revolution is a fairly fundamental change in a field, whereas mentality is concerned with the human mind and nature, which are not body and energy. Mental revolution concerns the mental, spiritual, spiritual, and values that are believed by a person or group of people in a small scope or even a country. The internalization of the Mental Revolution in Islamic Education is the deepening of fundamental changes in mentality, ways of thinking, ways of feeling, and ways 
of trust, all of which manifest in daily behavior and actions dalam pendidikan Islam. This can be done through: Modeling Strategies (modeling), Training and Habituation, Learning Taking Methods, Advising Strategies, Disciplinary Methods.

\section{Keywords: Revolution, Mental, Internalization, Education, Islam}

\section{A. PENDAHULUAN}

Indonesia merupakan Negara yang majemuk, heterogen, dari mulai bahasa, adat-istiadat maupun secara fundamental kegiatan sehari-hari. Dalam sejarah perjalanan bangsa Indonesia, setiap berganti Presiden, selalu terjadi perubahan. Perubahan yang dimaksud adalah perubahan mendasar dari segi haluan. Sebagai suatu bangsa, Indonesia sangatlah mutlak membutuhkan pendidikan. Pendidikan yang dimaksud adalah pendidikan yang bertujuan tidak sekedar proses memindahkan budaya atau ilmu (transfer of knowledge), tetapi juga sebagai proses transfer nilai (transfer of value). Peran pendidikan sangat penting dalam pembangunan suatu bangsa.

Dengan pendidikan suatu bangsa tidak mudah dijajah oleh bangsa lain dan dengan pendidikan suatu bangsa dapat mencapai kemajuan-kemajuan dan perkembanganperkembangan yang dapat membawa mewujudkan cita-cita bangsa. Dengan pendidikan juga, suatu bangsa dapat mengejar ketertinggalannya dari bangsa-bangsa lain di dunia. Kemudian, untuk menjelaskan arti Revolusi Mental, kita harus tahu terlebih dahulu arti dari masing-masing kata tersebut. Ada dua kata yang membutuhkan penjelasan, yaitu revolusi dan mental. Menurut Kamus Besar Bahasa Indonesia, revolusi adalah perubahan yang cukup mendasar 
dalam suatu bidang, sedangkan mental adalah bersangkutan dengan batin dan watak manusia, yang bukan bersifat badan dan tenaga. Revolusi mental menyangkut keadaan kejiwaan, roh, spiritual, dan nilai-nilai yang diyakini oleh seseorang atau sekelompok orang dalam sebuah ruang lingkup kecil atau bahkan sebuah negara. ${ }^{162}$ Untuk mewujudkan cita-cita bangsa Indonesia memerlukan pandangan - pandangan yang menuntut perubahan mendasar dari pola pendidikan di Indonesia selama ini. Pandangan yang saat ini menjadi perhatian banyak pihak adalah Revolusi Mental.

\section{B. PEMBahasan}

\section{Internalisasi}

Internalisasi diartikan sebagai penghayatan. Bisa juga diartikan sebagai "pendalaman; pengasingan". Internalisasi diartikan sebagai penggabungan atau penyatuan sikap, standart tingkah laku, pendapat dan seterusnya di dalam kepribadian Internalisasi menurut kamus ilmiah populer yaitu "pendalaman, penghayatan terhadap suatu ajaran, doktrin atau nilai sehingga merupakan keyakinan atau kesadaran akan kebenaran suatu doktrin atau nilai yang diwujudkan dalam sikap dan perilaku." Internalisasi pada hakikatnya adalah sebuah proses menanamkan sesuatu, yakni merupakan proses pemasukan suatu nilai pada seseorang yang akan membentuk pola pikirnya dalam melihat makna realitas pengalaman. ${ }^{163}$ Dalam proses internalisasi, menurut Muhaimin dikaitkan dengan 1991.

162 Depdikbud, Kamus Besar Bahasa Indonesia, Jakarta: Balai Pustaka,

163 Pius A. Partanto, dkk, Kamus Ilmiah Populer, Surabaya: Arkola, 1994, hlm, 267. 
pembinaan peserta didik atau anak asuh ada tiga tahap yang mewakili proses atau tahap terjadinya internalisasi ${ }^{164}$ yaitu:

a. Tahap Transformasi Nilai

Tahap tranformasi nilai merupakan komunikasi verbal tentang nilai. Pada tahap ini guru sekedar menginformasikan nilai-nilai yang baik dan yang kurang baik kepada peserta didik, yang semata-mata merupakan komunikasi verbal tentang nilai.

b. Tahap Transaksi Nilai

Tahap transaksi nilai adalah tahapan pendidikan nilai dengan jalan komunikasi dua arah atau interaksi antar peserta didik dengan guru bersifat interaksi timbal balik. Kalau pada tahap transformasi, komunikasi masih dalam bentuk satu arah, yakni guru aktif. Tetapi dalam transaksi ini guru dan peserta didik sama-sama memiliki sifat yang aktif. Tekanan dari komunikasi ini masih menampilkan sosok fisiknya daripada sosok mentalnya.

c. Tahap Transinternalisasi

Tahap transinternalisasi nilai yakni bahwa tahap ini jauh lebih dalam dari pada sekadar transaksi. Dalam tahap ini penampilan guru dihadapan peserta didik bukan lagi sosok fisiknya, melainkan sikap mentalnya (kepribadiannya).

Demikian juga peserta didik merespons kepada guru bukan hanya melalui gerakan/penampilan fisiknya saja, melainkan melalui sikap mental dan kepribadiannya. Oleh karena itu, dapat dikatakan bahwa dalam

164 Muhaimin, Paradigma Pendidikan Agama Islam, Bandung: PT. Remaja Rosdakarya, 2008, hlm, 301. 
transinternalisasi ini adalah komunikasi dua kepribadian yang masing masing terlibat secara aktif. Proses internalisasi terjadi apabila individu menerima pengaruh dan bersedia bersikap menuruti pengaruh itu dikarenakan sikap tersebut sesuai dengan apa yang ia percayai dan sesuai dengan sistem yang dianutnya.

Sikap demikian itulah yang biasanya merupakan sikap yang dipertahankan oleh individu dan biasanya tidak mudah untuk berubah selama sistem nilai yang ada dalam diri inidvidu yang bersangkutan masih bertahan. Dalam pemahaman internalisasi terdapat pendapat Soedijarto menyatakan apabila nilai yang akan ditanamkan dimaksudkan untuk sepenuhnya menjadi bagian sistem kepribadian setiap anak didik, maka tahap pengenalan dan pemahaman, penerimaan dan pengintegrasian, ketigaketiganya wajib ditempuh. Sedangkan tiga tahap tersebut merupakan teori yang dikemukakan oleh Krathwhol dan telah dikerucutkan oleh Soedijarto. ${ }^{165}$ Pada tahap-tahap internalisasi ini diupayakan dengan langkah-langkah sebagai berikut ${ }^{166}$ :

a. Menyimak, yakni guru memberi stimulus kepada peserta didik menangkap stimulus yang diberikan.

b. Responding, peserta didik mulai ditanamkan pengertian dan kecintaan terhadap tata nilai tertentu, sehingga memiliki latar belakang teoritik tentang sistem nilai, mampu memberikan argumentasi rasional

165 Soedijarto, Menuju Pendidikan Nasional Yang Relevan dan Bermutu, Jakarta : Balai Pustaka, 1993, Cet 4, hlm, 149.

166 HM. Chabib Thoha, Kapita Selekta Pendidikan Islam, Yogyakarta : Pustaka Pelajar, 1996, hlm, 94. 
dan selanjutnya peserta didik dapat memilliki komitmen tinggi terhadap nilai tersebut.

c. Organization, peserta didik mulai dilatih mengatur sistem kepribadia nnya disesuaikan dengan nilai yang ada.

d. Characterization, apabila kepribadian sudah diatur disesuaikan dengan sistem nilai tertentu dan dilaksanakan berturut-turut, maka akan terbentuk kepribadian yang bersifat satunya hati, kata dan perbuatan. Teknik internalisasi sesuai dengan tujuan pendidikan agama, khususnya pendidikan yang berkaitan dengan masalah aqidah, ibadah, dan akhlakul karim.

Proses internalisasi sangatlah penting dalam Revolusi Mental. Oleh karena revolusi mental merupakan bagian pendidikan nilai. Sehingga nilai - nilai tersebut dapat tertanam pada diri peserta didik, dengan pengembangan yang mengarah pada internalisasi Revolusi Mental yang merupakan tahap pada manifestasi manusia religius. Sebab tantangan arus globalisasi dan transformasi budaya bagi peserta didik dan bagi manusia pada umumnya yang difungsikan adalah nilai kejujurannya, yang dapat terwujud dalam kehidupan sehari-hari sehingga dapat terpercaya dan mengemban amanah masyarakat demi kemaslahatan.

\section{Revolusi Mental}

Dalam konteks Indonesia, istilah Revolusi Mental pertama kali dicetuskan Presiden RI pertama Soekarno dalam pidato kenegaraan memperingati proklamasi kemerdekaan tanggal 17 Agustus 1957. Revolusi Mental ala Soekarno adalah semacam Gerakan Hidup baru 
untuk menggembleng agar menjadi manusia baru yang berhati putih, berkemauan baja, bersemangat elang rajawali, berjiwa api yang menyala-nyala. ${ }^{167}$ Soekarno memandang saat itu revolusi nasional Indonesia sedang "mandek" padahal tujuan revolusi belum tercapai.Pada substansinya, makna yang terkandung dalam gagasan 'Revolusi Mental' adalah transformasi etos, yaitu perubahan mendasar dalam mentalitas, cara berfikir, cara merasa, dan cara mempercayai, yang semuanya menjelma dalam perilaku dan tindakan sehari-hari. Etos ini menyangkut semua aspek kehidupan, mulai dari ekonomi, politik, sains tekhnologi, seni, agama, dan sebagainya. Pada selanjutnya akan menjadikan mentalitas bangsa lambat laun akan berubah.

Pengorganisasian, rumusan kebijakan dan pengambilan keputusan diarahkan untuk proses transformasi itu. 168Tujuan dari Gerakan Nasional Revolusi Mental, yaitu ${ }^{169}$ :

a. Mengubah cara pandang, pola pikir, sikap, perilaku dan cara kerja, yang berorientasi pada kemajuan dan kemodernan, sehingga Indonesia menjadi bangsa besar dan mampu berkompetisi dengan bangsa-bangsa lain di dunia.

b. Membangkitkan kesadaran dan membangun sikap optimistik dalam menatap masa depan Indonesia

167 Arief Budimanta, dkk, Panduan Umum Gerakan Nasional Revolusi Mental, Jakarta : Kementerian Koordinator Bidang Pembangunan Manusia dan Kebudayaan, 2015, hlm, 1. ahmad-hifni.html

http://www.ahmadhifni.com/2014/10/tafsirrevolusi-mental-olehdiakses 4 Mei 2017

169 Arief Budimanta, dkk, Panduan Umum Gerakan..., hlm, 6. 
sebagai negara dengan kekuatan besar untuk berprestasi tinggi, produktif dan berpotensi menjadi bangsa maju dan modern dengan pondasi tiga pilar Trisakti.

c. Mewujudkan Indonesia yang berdaulat secara politik, berdikari secara ekonomi dan berkepribadian yang kuat melalui pembentukan manusia Indonesia baru yang unggul.

Adapun nilai-nilai yang ada di dalam Gerakan Nasional Revolusi Mental ada tiga, yaitu :

a. Integritas (jujur, dipercaya, berkarakter, bertanggung jawab).

b. Etos kerja (etos kerja, daya saing, optimis, inovatif dan produktif).

c. Gotong royong (kerja sama, solidaritas, komunal, berorientasi pada kemaslahatan). ${ }^{170}$

Selanjutnya, mengenai prinsip Gerakan Nasional Revolusi Mental yaitu: ${ }^{171}$

a. Revolusi Mental adalah gerakan sosial untuk bersama-sama menuju Indonesia yang lebih baik.

b. Harus didukung oleh tekad politik (political will) Pemerintah

c. Harus bersifat lintas sektoral.

d. Kolaborasi masyarakat, sektor privat, akademisi dan pemerintah.

170 Arief Budimanta, dkk, Panduan Umum Gerakan..., hlm, 8

171 http://revolusimental.go.id/tentang-gerakan/8-prinsip-revolusimental.html diakses 4

Mei 2017 
e. Dilakukan dengan program "gempuran nilai" (value attack) untuk senantiasa mengingatkan masyarakat terhadap nilai-nilai strategis dalam setiap ruang publik.

f. Desain program harus mudah dilaksanakan (user friendly), menyenangkan (popular) bagi seluruh segmen masyarakat.

g. Nilai-nilai yang dikembangkan terutama ditujukan untuk mengatur moralitas publik (sosial) bukan moralitas privat (individual).

h. Dapat diukur dampaknya dan dirasakan manfaatnya oleh warga masyarakat.

Di dunia pendidikan, Revolusi Mental ditekankan pada pembentukan karakter serta pengembangan kepribadian yang dapat membentuk jati diri bangsa. Maka tidaklah berlebihan bila kita menyebut guru adalah kunci revolusi mental. Revolusi mental memang harus dimulai dari dunia pendidikan dan secara simultan berjalan di bidang-bidang lainnya. Paling tidak selama 18 tahun waktu anak manusia dihabiskan di bangku pendidikan, mulai taman kanak-kanak hingga perguruan tinggi. Untuk itu tanggungjawab seorang guru semakin bertambah untuk ikut membentuk jati diri bangsa melalui peserta didiknya.

Asumsinya bahwa di sepanjang kehidupannya, manusia akan selalu dihadapkan pada masalah-masalah, rintangan-rintangan dalam mencapai tujuan yang ingin dicapai dalam kehidupan ini. Prinsip belajar sepanjang hayat ini sejalan dengan empat pilar pendidikan universal, yaitu: (1) learning to know, yang berarti juga learning to learn; (2) learning to do; (3) learning to be, dan (4) learning 
to live together. ${ }^{172}$ Learning to know atau learning to learn mengandung pengertian bahwa belajar itu pada dasarnya tidak hanya berorientasi kepada produk atau hasil belajar, akan tetapi juga harus berorientasi kepada proses belajar. Dengan proses belajar, peserta didik bukan hanya sadar akan apa yang harus dipelajari, akan tetapi juga memiliki kesadaran dan kemampuan bagaimana cara mempelajari yang harus dipelajari itu. Learning to do mengandung pengertian bahwa belajar itu bukan hanya sekedar mendengar dan melihat dengan tujuan akumulasi pengetahuan, tetapi belajar untuk berbuat dengan tujuan akhir penguasaan kompetensi yang sangat diperlukan dalam era persaingan global.

Learning to be mengandung pengertian bahwa belajar adalah membentuk manusia yang "menjadi dirinya sendiri”. Dengan kata lain, belajar untuk mengaktualisasikan dirinya sendiri sebagai individu dengan kepribadian yang memiliki tanggung jawab sebagai manusia. Learning to live together adalah belajar untuk bekerjasama. Hal ini sangat diperlukan sesuai dengan tuntunan kebutuhan dalam masyarakat global di mana manusia baik secara individual maupun secara kelompok tak mungkin bisa hidup sendiri atau mengasingkan diri bersama kelompoknya.

Revolusi mental merupakan harapan bangsa dan masyarakat saat ini menuju perubahan jati diri bangsa yang lebih baik. Melakukan revolusi mental guna membentuk revolusi karakter bangsa melalui dunia pendidikan, peneguhan dan penguatan ke-bhinekaan dan memperkuat

172 Sindhunata, Menggagas Paradigma Baru Pendidikan : Demokrasi, Otonomi, Civil

Society, Globalisasi. Yogyakarta : Kanisius. 2000, hlm. 116 
restorasi sosial merupakan bagian dari titik pusat utamanya. Membentuk generasi yang kreatif dan berintelektual menjadi latar belakang diwujudkannya revolusi mental bangsa. Oleh karena itu, bidang pendidikan sangat penting dalam menjaga pengarahan dan peningkatan mutu dan kesempurnaan aset hidup bangsa. Melalui pendidikanlah akan diperolehnya pemahaman-pemahaman baru dalam hal pengetahuan, keaktifan, dan kekritisan. Namun, dalam menjalankan proses revolusi mental tidak hanya dengan berbicara dan berdiskusi saja, tetapi harus diwujudkan dengan tindakan, yang dapat diaplikasikan dalam kehidupan.

\section{Internalisasi Revolusi Mental}

Internalisasi merupakan suatu proses penghayatan, pendalaman, penguasaan secara mendalam yang berlangsung melalui pembinaan, bimbingan dan sebagainya. Dalam hal ini penginternalisasian ini dikhususkan pada Revolusi Mental. Jadi internalisasi Revolusi Mental adalah suatu proses secara mendalam tentang nilai-nilai Revolusi Mental yang berjalan. Internalisasi revolusi mental dalam Pendidikan Islam dapat dilakukan melalui beberapa metode, yaitu:

a. Strategi Keteladanan (modelling)

Keteladanan merupakan sikap yang ada dalam pendidikan Islam dan telah dipraktekkan sejak zaman Rasulullah saw. Keteladanan ini memiliki nilai yang penting dalam pendidikan Islam, karena memperkenalkan perilaku yang baik melalui keteladanan, sama halnya memahami sistem nilai dalam 
bentuk nyata. ${ }^{173}$ Strategi dengan keteladanan adalah internalisasi dengan cara memberi contoh-contoh kongkrit pada anak didik. Dalam pendidikan pemberian contoh-contoh ini sangat ditekankan karena tingkah laku seorang pendidik mendapatkan pengamatan khusus dari para peserta didik.

Seperti perumpamaan yang mengatakan "Guru makan berjalan, murid makan berlari, disini dapat diartikan bahwa setiap perilaku yang ditunjukkan oleh guru selalu mendapat sorotan dan ditiru oleh peserta didiknya. Oleh karena itu guru harus senantiasa memberi contoh yang baik bagi peserta didiknya, khususnya dalam ibadah-ibadah ritual, dan kehidupan sehari-hari. Nabi Muhammad merupakan contoh atau teladan sosok manusia yang memiliki ketaqwaan luar biasa yang patut untuk diteladani. Melalui strategi keteladanan ini, memang seorang pendidik tidak secara langsung memasukan hal-hal terkait dengan keteladanan itu dalam rencana pembelajaran. Artinya, nilai-nilai moral religius seperti ketaqwaan, kejujuran, keikhlasan, dan tanggungjawab yang ditanamkan kepada peserta didik merupakan sesuatu yang sifatnya hidden curriculum.

Melalui cerita para tokoh penting dan pemutaran film seorang pendidik yang diteladani dengan harapan nilai-nilai yang terkandung di dalamnya dapat menjadi sesuatu yang menarik dan dapat ditiru atau diteladani oleh peserta didik.

173 Syafi'i Ma'arif, Pemikiran Tentang Pembaharuan Islam di Indonesia, Yogyakarta :

Tiara Wacana, 1991, hlm, 59. 
b. Latihan dan Pembiasaan

Ahmad Amin seperti dikutip Humaidi Tatapangarsa mengemukakan bahwa kebiasaan adalah perbuatan yang diulang-ulang sehingga menjadi mudah untuk dikerjakan. ${ }^{174}$ Mendidik dengan latihan dan pembiasaan adalah mendidik dengan cara memberikan latihan-latihan dan membiasakan untuk dilakukan setiap hari. Misalnya membiasakan salam jika bertemu sesama kawan atau guru. Apabila hal ini sudah menjadi kebiasaan, maka peserta didik akan tetap melaksanakannya walaupun ia sudah tidak lagi ada dalam sebuah lembaga pendidikan. Dari sini terlihat bahwasanya kebiasaan yang baik yang dilakukan oleh seorang pendidik akan membawa dampak yang baik pula pada diri peserta didiknya.

Strategi pembiasan ini sangat afektif untuk diajarkan kepada peserta didik yang masih puber, karena mereka belum terpengaruh oleh budayabudaya yang negatif dan arus globalisasi yang rusak. Apabila peserta didik dibiasakan dengan akhlak yang baik maka akan tercermin dalam kehidupan sehari-hari dengan pergaulan yang islami pula, kalau mereka tinggal di lingkungan yang baik maka sangat mudah berintraksi dengan pembiasaan lingkungan yang mencerminkan nilai-nilai agama.

c. Metode Mengambil Pelajaran

Mengambil pelajaran yang dimaksud disini adalah mengambil pelajaran dari beberapa kisah-kisah

174 Humaidi Tatapangarsa, Pengantar Kuliah Akhlak, Surabaya : Bina Ilmu, 1990, h, 67. 
teladan, fenomena, peristiwa-peristiwa yang terjadi, baik masa lampau maupun sekarang. Dari sini diharapkan peserta didik dapat mengambil hikmah yang terjadi dalam suatu peristiwa, baik yang berupa musibah atau pengalaman. Pelaksanaan strategi ini biasanya disertai dengan pemberian nasehat. Sang guru tidak cukup mengantarkan anak didik pada pemahaman inti suatu peristiwa, melainkan juga menasehati dan mengarahkan muridnya ke arah yang dimaksud.

Abd Al-Rahman Al-Nahlawi, mendefinisikan ibrah (mengambil Pelajaran) dengan kondisi psikis yang menyampaikan manusia untuk mengetahui intisari suatu perkara yang disaksikan, diperhatikan, diinduksikan, ditimbang-timbang, diukur dan diputuskan secara nalar, sehingga kesimpulannya dapat mempengaruhi hati menjadi tunduk kepadanya, lalu mendorongnya kepada perilaku berfikir sosial yang sesuai. ${ }^{175}$ Tujuan pedagogis dari pengambilan pelajaran adalah mengantarkan manusia pada kepuasan pikir tentang perkara agama yang bisa menggerakkan, mendidik atau menambah perasaan keagamaan.

d. Strategi Pemberian Nasehat

Rasyid Ridha seperti dikutip Burhanudin mengartikan nasehat (mauidzah) sebagai peringatan atas kebaikan dan kebenaran, dengan jalan apa saja yang dapat menyentuh hati dan membangkitkannya untuk mengamalkan". Metode mauidzah harus mengandung tiga unsur, yakni 1) uraian tentang

175 Abdurrahman an-Nahlawi, Prinsip-prinsip dan Metode Pendidikan Islam, Pent. Dahlan

dan Sulaiman, Bandung : CV. Diponegoro, 1992, h, 390. 
kebaikan dan kebenaran yang harus dilakukan oleh seseorang, misalnya: tentang sopan santun, 2) motivasi untuk melakukan kebaikan, 3) peringatan tentang dosa yang muncul dari adanya larangan, bagi dirinya dan orang lain. 176

e. Metode Kedisiplinan

Pendidikan dengan kedisiplinan memerlukan ketegasan dan kebijaksanaan. Ketegasan maksudnya seorang pendidik harus memberikan sangsi pada setiap pelanggaran yang dilakukan oleh anak didik, sedangkan kebijaksanaan mengharuskan seorang guru memberikan sangsi sesuai dengan jenis pelanggaran tanpa dihinggapi emosi atau dorongan-dorongan lain. Takzir adalah hukuman yang dijatuhkan pada anak didik yang melanggar. Hukuman ini diberikan bagi yang telah berulangkali melakukan pelanggaran tanpa mengindahkan peringatan yang diberikan.

Lingkungan sebuah lembaga pendidikan aturanaturan yang sudah menjadi tata tertib harus ditaati oleh setiap peserta didik dan pengurusnya. Sedangkan pelaksanaan ta'zir biasanya dilakukan oleh pengurus itu sendiri. Semua itu demi menjaga kedisiplinan untuk kelancaran proses belajar mengajar di lembaga itu sendiri. Dari segi metode yang digunakan, internalisasi Revolusi Mental dalam pembelajaran juga harus dilakukan secara komprehensif. Pendidik harus dapat menjadi teladan bagi anak didiknya dalam bertindak dan bertutur kata. Pelajar perlu disiapkan agar

176 Tamyiz Burhanudin, Akhlak Pesantren Solusi bagi Kerusakan Akhlak, Yogyakarta : ITTAQA Press, 2001, h, 56. 
menjadi generasi muda yang mandiri dengan mengajarkan dan memfasilitasi mereka dalam pembuatan keputusan moral secara bertanggungjawab. Selain itu, pendidik perlu membekali anak didiknya dengan keterampilan-keterampilan akademik dan sosial.

Sejalan dengan internalisasi revolusi mental, ditemukan beberapa faktor, yaiku faktor pendukung dan penghambat internalisasi Revolusi Mental. Faktor pendukung dalam pelaksanaan internalisasi Revolusi Mental yaitu : Kemampuan guru yang cukup professional dalam mengelola proses pembelajaran, Adanya dukungan dari wali murid dalam memantau dan perkembangan proses pembelajaran. Sedangkan Faktor penghambat dalam pelaksanaan internalisasi Revolusi Mental, adalah: Guru mengalami kendala pada keterbatasan waktu pembelajaran yang tidak sesuai dengan materi yang begitu banyak, Kurangnya antusiasme peserta didik terhadap pembelajaran.

f. Upaya yang dilakukan guru dalam mengatasi kendala dalam pelaksanaan internalisasi Revolusi Mental pada proses pembelajaran diantaranya adalah :

1) Guru lebih teliti dan kreatif lagi dalam menentukan nilai Revolusi Mental yang sesuai dengan materi.

2) Guru selalu datang tepat waktu sesuai dengan jam pelajaran. Untuk meminimalisir termakannya waktu pelajaran oleh jam pelajaran sebelumnya. Selain itu dengan keterbatasan waktu pembelajaran guru memberikan tugas pada peserta didik untuk dikerjakan di rumah. 
3) Guru membangkitkan dorongan kepada anak didik untuk belajar dengan memberikan perhatian secara maksimal kepada peserta didik.

4) Guru memberikan hadiah terhadap peserta didik yang aktif guna memotivasi semangat peserta didik untuk lebih giat lagi. Disisi lain, peserta didik yang belum aktif akan termotivasi untuk bisa ikut berpartisipasi dalam proses pembelajaran.

5) Guru berupaya untuk menciptakan persaingan (kompetisi) positif di antara peserta didiknya untuk meningkatkan keaktifan dan prestasi belajarnya.

\section{KESIMPULAN}

Berdasarkan uraian diatas dapat disimpulkan bahwa Internalisasi Revolusi Mental, adalah sebagai berikut:

1. Internalisasi Revolusi Mental adalah suatu proses secara mendalam tentang nilai-nilai Revolusi Mental yang berjalan. Proses internalisasi sangatlah penting dalam Revolusi Mental. Oleh karena Revolusi Mental merupakan bagian pendidikan nilai. Sehingga nilai - nilai tersebut dapat tertanam pada diri peserta didik, dengan pengembangan yang mengarah pada internalisasi Revolusi Mental yang merupakan tahap pada manifestasi manusia religius.

2. Internalisasi Revolusi Mental dalam Pendidikan Islam adalah pendalaman perubahan yang mendasar dalam mentalitas, cara berfikir, cara merasa, dan cara mempercayai, yang semuanya menjelma dalam perilaku dan tindakan sehari-hari. Hal ini dapat dilakukan melalui : Strategi Keteladanan (modelling), Latihan dan Pembiasaan, 
Rubini : Internalisasi Revolusi Mental Dalam Pendidikan Islam

Metode Mengambil Pelajaran, Strategi Pemberian Nasehat, Metode Kedisiplinan. 


\section{DAFTAR PUSTAKA}

An-Nahlawi, Abdurrahman, Prinsip-prinsip dan Metode Pendidikan Islam, Pent.Dahlan dan Sulaiman, Bandung : CV. Diponegoro, 1992.

Arifin, Zaenal, Metodologi Penelitian Pendidikan, Surabaya: Lentera Cendekia, 2008.

Budimanta, Arief, dkk, Panduan Umum Gerakan Nasional Revolusi Mental,Jakarta : Kementerian Koordinator Bidang Pembangunan Manusia dan Kebudayaan, 2015.

Burhanudin, Tamyiz, Akhlak Pesantren Solusi bagi Kerusakan Akhlak, Yogyakarta : ITTAQA Press, 2001.

Depdikbud, Kamus Besar Bahasa Indonesia, Jakarta: Balai Pustaka, 1991.

\section{http:/ / revolusimental.go.id/tentang-gerakan/8-prinsip-revolusi-} mental.html, diakses 4 Mei 2017

\section{http://www.ahmadhifni.com/2014/10/tafsirrevolusi-mental-oleh-} ahmad-hifni.html, diakses 4 Mei 2017

Ma'arif, Syafi'i, Pemikiran Tentang Pembaharuan Islam di Indonesia, Yogyakarta : Tiara Wacana, 1991.

Muhaimin, Paradigma Pendidikan Agama Islam, Bandung: PT. Remaja Rosdakarya, 2008

Partanto, Pius A. dkk, Kamus Ilmiah Populer, Surabaya: Arkola, 1994.

Sindhunata, Menggagas Paradigma Baru Pendidikan : Demokrasi, Otonomi,

Civil Society, Globalisasi. Yogyakarta : Kanisius. 2000.

Soedijarto, Menuju Pendidikan Nasional Yang Relevan dan Bermutu, Jakarta :Balai Pustaka, 1993, Cet 4.

Tatapangarsa, Humaidi, Pengantar Kuliah Akhlak, Surabaya : Bina Ilmu, 1990. 
Rubini : Internalisasi Revolusi Mental Dalam Pendidikan Islam

Thoha, HM. Chabib, Kapita Selekta Pendidikan Islam, Yogyakarta: Pustaka Pelajar, 1996. 